\title{
AYELET Is Investor-State Arbitration BANAI Unfair? A Freedom-Based Perspective
}

\begin{abstract}
Investor-state-dispute-settlement (ISDS) is an arbitration mechanism to settle disputes between foreign investors and host-states. Seemingly a technical issue in private international law, ISDS procedures have recently become a matter of public concern and the target of political resistance, due to the power they grant to foreign investors in matters of public policies in the countries they invest in. This article examines the practice of ISDS through the lenses of liberal-statist theories of international justice, which value self-determination. It argues that the investorstate arbitration system illustrates how liberal-statist theories of international distributive justice ought to care about relative socioeconomic disadvantage, contra the sufficiency principle that they typically defend. The sufficiency principle draws on a questionable conception of the freedom that self-determination consists in.
\end{abstract}

Keywords: Investor-state arbitration; self-determination; international distributive justice; negative freedom; opportunity freedom; value of liberty; ISDS

\section{Introduction}

In August 2011, an international arbitration tribunal awarded Chevron Corporation $\$ 96$ million, in connection with a claim brought by the Corporation against the Government of Ecuador, for violating a bilateral investment treaty between Ecuador and the United States. This ruling is a step in a legal saga known as the Chevron / Ecuador lawsuits, which began with a class action suit filed in 1993 by Ecuadorian citizens from the Oriente region against Texaco (an oil corporation acquired by Chevron in 2001). The allegations were that Texaco's oil drilling operations in the region between 1964 and 1990 had led to levels of pollution which were having devastating consequences for the rainforest environment, the rivers, and the health and livelihood of the inhabitants. Earlier in 2011, an Ecuadorian court ruled against Chevron, and ordered it to pay $\$ 8.6$ billion in compensation and for cleaning costs as well as to issue a public apology. The case involved litigations in the United States, Ecuador, Canada, Brazil, Argentina and the Permanent Court of Arbitration, The Hague. ${ }^{1}$ The corporation reportedly vowed to fight against the lawsuits 'until hell freezes over' and then 'fight it out on the ice,'2 and warned

1 For an overview and information about the lawsuits see, 'Texaco/Chevron Lawsuits (re Ecuador) - Business and Human Rights Resource Centre' <https://business-humanrights.org/en/texacochevron-lawsuits-re-ecuador> (Accessed: 15 May 2017).

2 John Otis, 'Chevron vs. Ecuadorian Activists' (2009), <https://www.pri.org/stories/2009-05-03/chevron-vsecuadorean-activists?page $=0 \% 2 \mathrm{C} 2>$ (Accessed: 15 May 2017). 
that the litigants on both sides may face 'a lifetime of appellate and collateral litigation.' 3 Nearly 25 years after the lawsuits were filed, the pollution endures and, with it, the damages to the environment and to the health and livelihood of the affected communities.

The Chevron / Ecuador lawsuits particularly stand out among the more than 767 known cases of investor-state dispute arbitration ${ }^{4}$ for their significance and time span. Still, the case helps illustrate why investor-state arbitration seemingly a technical practice in international investment law - has come to draw broader public and political attention. ${ }^{5}$ Investor-state-dispute-settlement (ISDS) is an arbitration mechanism, typical of bilateral investment treaties (BITs). These international treaties include provisions to protect foreign investment from arbitrary host-state power, designed formally to safeguard the rule of law through fair and equitable treatment, non-discrimination, and protection from expropriation without compensation. Importantly, the provisions grant private investors the right to take legal action against host-states directly, by brining claims of treaty violation before international arbitration tribunals, outside the state's own legal system.

Whereas the value and sense of an autonomous arbitration procedure is evident, investor-state arbitration has recently emerged as a tool of affluent multinational corporations to attain unwarranted priority for the protection of their revenues over legitimate local public interests - as cases brought by corporations to arbitration challenge governments' policies on matters of public health, environmental protection, taxation, and labour rights. A European Commission's factsheet on Investment Protection and Investor-to-State Dispute Settlement in EU Agreements notes that 'some of the most recent cases brought by investors against states have given rise to strong public concerns. The main concern is that the current investment protection rules may be abused to prevent countries from making legitimate policy choices.' ${ }^{6}$ A commentary for Cato Institute's Free Trade Bulletin describes the ISDS as 'an unnecessary, unreasonable, and unwise provision to include in trade agreements. ${ }^{7}$ In 2017, Ecuador cancelled all its BITs, joining India, Indonesia, South Africa and

3 'Press Release: Chevron Calls for Dismissal of Ecuador Lawsuits' (2007), <https://www.chevron.com/stories/ chevron-calls-for-dismissal-of-ecuador-lawsuit> (Accessed: 15 May 2017).

4 UNCTAD, ILA Issues Note no. 1 (2017a), p. 2. < http://investmentpolicyhub.unctad.org/Upload/Documents/ diaepcb2017d1_en.pdf> (Accessed: 12 June 2017).

5 Christopher Wytock, 'Some Cautionary Notes on the Chevronization of International Litigation', Stanford Journal of Complex Litigation 1/2 (2013), 467-486, pp. 471-2; Maya Steinitz and Paul Gowder, 'Transnational Litigation As a Prisoner's Dilemma', North Carolina Law Review 94/3 (2016), 751-816, pp. 759-61.

6 The European Commission, 'Investment Protection and Investor-to-State Dispute Settlement in EU Agreements' (2013), p. 5 <http://trade.ec.europa.eu/doclib/docs/2013/november/tradoc_151916.pdf> (Accessed: 12 June 2017).

7 Daniel Ikenson, 'A Compromise to Advance the Trade Agenda: Purge Negotiations of Investor-State Dispute Settlement', Free Trade Bulletin 57 (2014), 1-4, p. 1 <https://www.cato.org/publications/free-trade-bulletin/ compromise-advance-trade-agenda-purge-negotiations-investor-state> (Accessed: 12 June 2017). 
Bolivia. ${ }^{8}$ The UN Conference on Trade and Development (UNCTAD) has also launched an appeal for reform in international investment agreements, ${ }^{9}$ inter alia, to address a legitimacy crisis in international investment arbitration. ${ }^{10}$

The purpose of this article is to scrutinize the normative and theoretical underpinnings of the controversy surrounding investor-state arbitration. In particular, it asks how the practice might raise challenges for contemporary liberal theories of self-determination. Liberal-statist theories value state selfdetermination as a core principle of international justice; ${ }^{11}$ as a result, when investor-state arbitration is arguably used as an instrument to undermine the legitimate public policy choices of host countries, such theories face the following dilemma. On the one hand, self-determination is closely associated with the freedom of states to enter international treaties, agreements, and contracts. This freedom is an important component of the meaningful exercise of selfdetermination; ${ }^{12}$ honouring it means that sub-optimal and even poor decisions that states freely make ought to be respected. ${ }^{13}$ On the other hand, the outcomes of international trade arbitration sometimes impose such prohibitive costs on domestic policy choices, that this arguably undermines the very preconditions for state self-determination. Should liberal-statist theories therefore accept or reject the practice of investor state arbitration, and on what grounds? Does investor-state arbitration constitute an exercise of, or an infringement upon, self-determination?

An initial observation and intuition that motivates this inquiry is that the practice is indeed liable to objections, as it tends to reinforce inequalities, and it creates (at least in some cases) additional burdens for worse-off and marginalized groups, which struggle to protect their vital interests and rights, and to obtain their fair share of benefits from social cooperation. In a nutshell, my argument will be the following: our ambivalent intuitions about investorstate arbitration reveal a deeper ambiguity concerning the specific conception of freedom which ought to underpin our understanding of self-determination; once the correct conception of freedom is unpacked, it becomes apparent that

8 Investment Treaty News, 'Ecuador Denounces Its Remaining 16 BITs and Publishes CAITISA Audit Report' (2017), <https://www.iisd.org/itn/2017/o6/12/ecuador-denounces-its-remaining-16-bits-and-publishes-caitisa-auditreport/> (Accessed: 01 July 2017).

9 UNCTAD, World Investment Report 2017 (2017b), pp. 105-147 <http://unctad.org/en/PublicationsLibrary/ wir2017_en.pdf> (Accessed: 12 June 2017).

10 Susan Franck, 'The Legitimacy Crisis in Investment Treaty Arbitration: Privatizing Public International Law through Inconsistent Decisions,' Fordham Law Review 73/4 (2005), 1521-1625.

11 John Rawls, The Law of Peoples (Cambridge: Harvard University Press, 1999); David Miller, National Responsibility and Global Justice (Oxford: Oxford University Press, 2007); Andrew Altman and Christopher H. Wellman, A Liberal Theory of International Justice (Oxford: Oxford University Press, 2009).

12 Rawls (1999), p. 37.

13 Christopher H. Wellman, A Theory of Secession: The Case for Political Self-Determination (Cambridge: Cambridge University Press, 2005), pp. 38-47. 
liberal-statist theories do have the resources to criticize and reject some forms of investor-state arbitration, namely those which occur within a context of steep inequalities between the actors involved. In so doing, this article makes not only a contribution to the debate of the moral permissibility of investor-state arbitration, but also a broader contribution to the general debate on global distributive justice, in that it argues that liberal statists should also be worried by global and international inequalities.

The argument proceeds as follows. The next section looks at the practice of investor-state arbitration, to help illustrate what is at stake. The following section shows how the dominant liberal-statist view understands self-determination as grounded in a 'traditional' (or Hobbesian) conception of negative freedom, and endorses, as a result, the sufficiency principle as a standard of international distributive justice. Relative inequality among participants in the practice of investment treaties and arbitration is not, on this view, a problem of justice, insofar as all participants are above a designated threshold of sufficiency. I then move on to argue that the conception of freedom that informs the threshold position is questionable and to propose a liberal-egalitarian conception of (negative) freedom as an alternative. On this interpretation, relative inequalities among contracting matter: where the gaps are considerable, interaction between unequal parties can longer been seen as a free exercise of self-determination, insofar as the value of liberty for all participants in exercising self-determination, including the worse-off, is not safeguarded. From this theoretical vantage point, self-determination-based objections to the practice of investor-state arbitration emerge.

\section{Investor state arbitration - what is at stake?}

According to the UNCTAD records for 2016, there are 3,324 international investment agreements (IIAs) in force worldwide. 2,957 of the IIAs are bilateral investment BITs and 367 are other treaties that include investment provisions (TIPs). ${ }^{14} \mathrm{~A}$ BIT is a treaty between two states that determines the conditions for foreign direct investment by nationals and companies of one state in another, and it typically includes provisions that establish investment state-arbitration as a mechanism to resolve disputes arising from the treaty. Other agreements with investment provisions include plurilateral and regional trade treaties e.g., NAFTA, ASEAN and CETA ${ }^{15}$, as well as sectorial agreements - e.g., the

14 UNCTAD (2017b), p. 111.

15 NAFTA = North American Free Trade Association; ASEAN = Association of Southeast Asian Nations; CETA= CanadaEuropean Union (EU) Comprehensive Economic and Trade Agreement. 
ECT. ${ }^{16}$ The trend and pace of growth in the number of IIAs is notable. The first BIT was signed in 1959 between The Federal Republic of Germany and Pakistan, ${ }^{17}$ growing to under 400 BITs in 1989 and nearly 2000 by $1999,{ }^{18}$ then passing 3,500 in 2016. Agreements are in power worldwide, among countries and regions of nearly all income and development levels, and they constitute a principal part of the framework for foreign direct investment. ${ }^{19}$

Investor-state arbitration is an important component of the rules that govern foreign direct investment and it emerges as a prevalent practice with global reach. ${ }^{20}$ As Benedict Kingsbury and Stephan Schill argue, 'Investor-State arbitration, and in particular arbitration based on international investment treaties, is not simply dispute resolution. It is also a structure of global governance.' ${ }^{21}$ Two features of investor-state arbitration make it a special practice in international law. First, private companies and investors have the right to bring cases directly against host-states before international arbitral tribunals. Claimants do not need go through their home-country's institutions, or another organ of public international law. Second, the arbitral tribunals are not courts, and are not subject to rules that apply to public courts with regard to continuity and transparency. There is more than one system of arbitration rules in power, as well as several arbitration bodies to choose from, in addition to the possibility, pending agreement by the parties, of appointing an ad hoc tribunal. ${ }^{22}$ The International Center for Settlement of Investment Disputes (ICSID) of the World Bank Group is a prominent arbitral centre that operates according to the ICSID Convention. Another commonly used set of arbitration rules is the UNCITRALArbitration Rules of the UN Commission on International

16 ECT = Energy Charter Treaty. Not all TIPs include international investor-state arbitration as the obligatory mechanism for settlement of disputes arising from the contract, but a substantive subset of them does. Seven TIPs were concluded in 2016. Three of them include provisions of robust investment protection, including ISDS, and additional three include provision for softer investment protection, see UNTCAD (2017b), p. 112.

17 UNCTAD, 'Bilateral Investment Treaties 1995-2006: Trends in Investment Rulemaking' (2007), p. 1, <http://unctad. org/en/docs/iteiia20065_en.pdf> (Accessed: 23 April 2017).

18 UNCTAD, 'Bilateral Investment Treaties 1959-1999' (2000), p. 22, <http://unctad.org/en/Docs/poiteiiad2.en.pdf> (Accessed: 23 April 2017).

19 According to an OECD survey: 'Over time, ISDS through international arbitration has become a common feature of investment treaties - only 108 treaties, or $6.5 \%$ of the sample, do not provide for international arbitration.' $93 \%$ of international investment treaties had provisions regarding investor-state arbitration, with variation in these provisions across treaties. See, Joachim Pohl, Kekeletso L. Mashigo, and Alexis Nohen, 'Dispute settlement provisions in international investment agreements: A large sample survey,' OECD Working Papers on International Investment 2 (2012), p. 2, 11. <http://www.oecd.org/daf/inv/investment-policy/WP-2012_2.pdf> (Accessed: 17 August 2017). See also, UNCTAD (2000); UNCTAD (2007).

20 For an overview of the volume and global trends in foreign direct investment, see UNCTAD (2017b), pp. 10-25, 222-229.

21 Benedict Kingsbury and Stephan Schill, 'Investor-State Arbitration as Governance: Fair and Equitable Treatment, Proportionality, and the Emerging Global Administrative Law,' NYU School of Law, Public Law Research Paper No. 09-46 (2009), p. 1, <http://dx.doi.org/10.2139/ssrn.1466980> (Accessed: 14 Nov 2017).

22 On the variety of arbitral institutions see e.g., Suha Jubran-Ballan, 'Investment Treaty Arbitration and Institutional Backgrounds: An Empirical Study,' Wisconsin International Law Journal 34/1 (2016), 31-90, pp. 39-49. 
Trade Law. Pace an optimistic analysis that identifies a democratic potential in multipolar international regimes, with a multiple rule-makers and ruletakers, ${ }^{23}$ cases of investor-state arbitration suggest that multi-polarity enables the better-off parties to pick and choose a forum to their advantage.

According to the UNCTAD records, there are 767 known cases of investorstate arbitration, ${ }^{24} 259$ of which pending (as of 2017). ${ }^{25}$ Not all cases are known, nor are all rulings - due to the private nature of the arbitration procedures, which enables parties to keep the litigation confidential. Argentina, Venezuela, The Czech Republic, Spain and Egypt are, in descending order, the five most frequently sued countries in publicly known investor-state arbitrations. The United States is the most frequent home country of companies that brought cases to arbitration (148 cases), followed by the Netherlands (92), The United Kingdom (67), Germany (55), and Canada (44). ${ }^{26}$ Claimants challenge, or seek compensation, pertaining to a wide range of public policy areas, including: environmental policies (e.g., Vattenfallv. Germany, ${ }^{27}$ Pac Rimv. El Salvador ${ }^{28}$ ), public health (e.g., Philip Morris v. Uruguay ${ }^{29}$ ), labour conditions (e.g., Veolia $v$. Egypt ${ }^{30}$ ), and taxation (e.g., Vodafone $v$. India ${ }^{31}$ ). In the case of Veolia $v$. Egypt, the company filed an arbitration claim in 2012, under Egypt-France BIT, pertaining to its contract with the Governorate of Alexandria to provide waste management services. The dispute concerns 'Egypt's alleged refusal to modify the contract in response to inflation and the enactment of new labour legislation.' ${ }^{32}$ The new labour legislation included a raise in monthly minimum wage from 400 to 700 Egyptian pounds (\$69 to \$99). 33 The case of Vodafone $v$. India pertains to an $\$ 11$ bn purchase by Vodafone of Indian-based Hutchison

23 Jonathan Kuyper, 'Global Democratization and International Regimes Complexity,' European Journal of International Relations 20/3 (2014), 620-646.

24 UNCTAD (2017a), p. 2.

25767 is the cumulative number of known cases since 1987, of them 259 pending, see: UNCTAD, Investment Policy Hub <http://investmentpolicyhub.unctad.org/ISDS> (Accessed: 30 June 2017).

26 Cumulative numbers for 1987-2016, see UNCTAD (2017a).

27 Vattenfall $A B$ and others $v$. Federal Republic of Germany (II)(ICSID Case No. ARB/12/12) <http:// investmentpolicyhub.unctad.org/ISDS/Details/467> (Accessed: 12 June 2017).

28 Pac Rim Cayman LLC v. Republic of El Salvador (ICSID Case No. ARB/o9/12) <http://investmentpolicyhub.unctad. org/ISDS/Details/356> (Accessed: 12 June 2017).

29 Philip Morris Brand Sàrl (Switzerland), Philip Morris Products S.A. (Switzerland) and Abal Hermanos S.A. (Uruguay) v. Oriental Republic of Uruguay (ICSID Case No. ARB/10/7) <http://investmentpolicyhub.unctad.org/ ISDS/Details/368> (Accessed: 12 June 2017).

30 Veolia Propreté v. Arab Republic of Egypt (ICSID Case No. ARB/12/15) <http://investmentpolicyhub.unctad.org/ ISDS/Details/458> (Accessed: 12 June 2017).

31 Vodafone International Holdings BV $v$. India, 2014 <http://investmentpolicyhub.unctad.org/ISDS/Details/581> (Accessed: 12 June 2017).

32 Veolia Propreté v. Arab Republic of Egypt (ICSID Case No. ARB/12/15) <http://investmentpolicyhub.unctad.org/ ISDS/Details/458> (Accessed: 12 June 2017).

33 On the changes in Egypt's monthly minimum wage see: 'Egypt Minimum Monthly Wages 2012-2017 <https:// tradingeconomics.com/egypt/minimum-wages> (Accessed: 12 June 2017); 'Egypt Sets Minimum Monthly Ways to 69\$', <http://www.ilo.org/dyn/travail/docs/438/_www.businessweek.com_ap_financialnews_D9J5E7VGo.pdf> (Accessed: 13 June 2017). 
Whampoa's telecom assets in 2007. Following India's demand from Vodafone to pay taxes on the transaction, the company filed a claim in 2014. Both cases are pending. In the infamous Philip Morris $v$. Uruguay case, anti-smoking measures enacted by the Ministry of Public Health and the President were challenged. The regulations, introduced in 2008, included single packaging and a requirement for graphic depiction of smoking-related health damages on packages. The claim was filed in 2010, and eventually in 2016 a ruling in favor of Uruguay was delivered by the tribunal. In the case of Pacific Rim $v$. El Salvador, the company was denied license for a gold mining operation, where it has exploration concession. The license was denied in light of the project's environmental risks, including potential pollution of drinking water. The claim was filed in 2009 and a ruling in favor of the state was delivered in 2016.

As this brief overview should illustrate, it is not evidently and immediately clear, from a liberal-statist perspective, that the practice of investor-state arbitration is wrong. If states may permissibly decide to enter contracts and make international agreement, it should be equally permissible to hold them accountable for that. Still, cases of investor-state arbitration indicate that the practice also serves to add hurdles and burdens on states and their citizens attempting to improve domestic policies pertaining to the environment, health and socioeconomic justice. What is more, the interaction between domestic and international practices is a matter of concern for liberal-statist justice. ${ }^{34}$ In the following section, I examine the practice of investor-state arbitration in light of liberal-statist theories of justice that value self-determination and endorse a sufficiency principle as a standard of international distributive justice.

\section{Investor-state arbitration and international justice: The liberal-statist sufficiency principle}

What, if anything, is wrong with the practice of investor-state arbitration from the perspective of liberal-statist theories of global justice committed to selfdetermination? This section proposes a brief reconstruction (which I take to be fairly non-controversial) of the dominant liberal-statist outlook on global justice, according to which sufficientarian principles of distributive justice should hold internationally and egalitarian ones domestically. ${ }^{35}$ On this view, the self-determination of a people or state is a primary principle of international justice. ${ }^{36}$ In The Law of Peoples, Rawls famously defends eight principles of

34 See e.g., Ayelet Banai, Miriam Ronzoni and Christian Schemmel (eds.), Social Justice, Global Dynamics: Theoretical and Empirical Perspectives (London: Routledge, 2011).

35 I draw here on an earlier discussion in Ayelet Banai, 'Freedom Beyond the Threshold: Self-Determination, Sovereignty, and Global Justice,' Ethics and Global Politics 8/1 (2015), 21-41. Major and often-cited contributions include: Rawls (1999a); Miller (2007); Altman and Wellman (2009). The discussion here does not aim to challenge the liberal-statist perspective as such, but to suggest and adjustment through an internal critique.

36 The question of whether the subjects of political self-determination are peoples, nations, or states is bracketed here. See discussion, e.g., in Ayelet Banai and Margaret Moore (eds.), 'Symposium: Theories of Territory beyond Westphalia', International Theory 6/1 (2014), 98-190. 
international justice to safeguard the international freedom and equality of peoples. Self-determination entitles a people to domestic self-government understood as a right to non-interference and self-defence against aggression, and as encompassing the right to sign treaties and engage in undertakings as equal parties. The main obligations connected to self-determination according to the Law of Peoples are the duty to respect the domestic self-government rights of other peoples; to 'observe treaties and undertakings'; and to 'honor human rights.' Finally, peoples have a mutual duty of assistance to help 'burdened societies' to achieve the preconditions for a just or at least decent political and social regime. ${ }^{37}$ The cut-off point of the duty of assistance is the achievement of 'just liberal or decent basic institutions. ${ }^{38}$ Where appropriate, this duty may involve transfer of resources, wealth and knowledge from well-ordered and better-off societies to burdened ones; however, beyond the cut-off point, international disparities in wealth are not seen as an international injustice. In sum, this conception of self-determination confers formal legal equality and freedom to the right holders in the international sphere coupled with threshold conditions, necessary for the exercise of self-determination and for liberal and just or decent basic institutions to function domestically.

In National Responsibility and Global Justice, David Miller ${ }^{39}$ also defends a threshold conception of the conditions for self-determination. Nations are entitled, in virtue of their right to national self-determination, to rights of selfgovernment and non-interference, including territorial integrity and control over national borders (subject to considerations of human rights). ${ }^{40}$ To the extent that nations govern themselves autonomously they are responsible, for better and worse, for the outcomes of their decisions; they are entitled to enjoy the benefits or advantageous choices and are liable to bear the burden of disadvantageous ones. ${ }^{41}$ Alongside the principle of national responsibility, the theory defends international duties of aid and non-exploitation, including the 'the duty to abstain from materially harming another state'; and the duty 'not to exploit states that are one-sidedly vulnerable to your actions.' Further international duties are connected to the rights of others to exercise their national self-determination. For example, resources should be distributed in a way that enables all nations to 'provide for the basic needs of their members,' so that the exercise of collective autonomy is at all possible..$^{42}$ In interaction among poor and wealthy nations there are obligations of non-exploitation in

37 Rawls (1999a), p. 37, 106.

38 Ibid, p. 118.

39 Miller (2007).

40 Ibid, pp. 2015-7.

41 Ibid, Ch. 5 .

42 David Miller, On Nationality (Oxford: Oxford University Press, 1995), pp. 104-5. 
international trade and by international institutions, and sometimes of material assistance if those at the bottom of an unequal international order do not have an opportunity to attain minimal levels of self-determination. ${ }^{43}$

These important liberal-statist theories endorse a sufficiency, threshold principle of international distributive justice. Self-determination requires that all peoples or nations are given the minimal material conditions necessary for the exercise of self-government. Beyond this threshold, relative levels of poverty and wealth are not as such a matter of injustice. According to the Law of Peoples, the duty of assistance consists in a requirement to help bring peoples confronted with unfavourable conditions to the threshold of being 'able to manage their own affair reasonably and rationally [...] After this is achieved, further assistance is not required even though the now well-ordered society may still be relatively poor.'44 National responsibility, as a perspective on global justice, includes 'an obligation to provide political communities with the opportunity to achieve justice internally, where this means ensuring that they have an adequate resource base, and a tolerable economic environment, against which to make their decisions.' 45

Which implications does this have for the practice of investment treaties and arbitration? A straightforward implication is that insofar as the states that sign and enter investment treaties, which include provisions on investor-state arbitration are above the sufficiency threshold designated by the theories, there is no injustice in the interaction among them. Above the threshold, a state's decision to enter an investment treaty, and subsequently exclude policy options from being taken in the future, is an exercise of self-determination - of its freedom to enter international treaties and agreements. Importantly, freedom is here conceived of as 'Hobbesian' or conventional negative freedom; being free means being neither physically coerced, nor legally or otherwise formally prohibited, nor subject to critical threats, nor bodily disabled. ${ }^{46}$ In the context of a political community, the equivalent of freedom from bodily disablement consists in having the basic institutional and material capacity to act as a

43 Miller (2007), pp. 75-7, 251-3.

44 Rawls (1999a), p. 111.

45 David Miller, 'National Self-Determination and Global Justice', in Citizenship and National Identity (Cambridge: Polity Press, 2000), 161-79, p. 176.

46 Absence of bodily disablement of individuals is equivalent, in the context of political communities, to minimally functional institutions. On classification of negative conceptions of freedom see, Ian Carter, 'Choice, Freedom and Freedom of Choice,' Social Choice and Welfare 22/1 (2004), 61-81, pp. 74-6; Ian Carter, A Measure of Freedom (Oxford: Oxford University Press, 1999) Ch. 1; Keith Dowding and Martin van Hees, 'Counterfactual Success and Negative Freedom,' Economics and Philosophy 23 (2007), 141-62, pp. 147-9; Charles Taylor, 'What is Wrong with Negative Liberty?', in Alan Ryan (ed.), The Idea of Freedom: Essays in the Honour of Isaiah Berlin (Oxford: Oxford University Press, 1979), 175-94. 
political collective. ${ }^{47}$

From the vantage point of liberal-statist theory, the fairness of the practice of investor-state arbitration and it compatibility with the principle of selfdetermination depend on whether sufficientarian principles of international justice are satisfied. Insofar as the participating states are above the sufficiency threshold and are not subject to direct coercion by one another, the conditions for exercising self-determination and the demands of international distributive justice are met. Applying theoretical principles to real-world cases is, to be sure, a complex task. Nonetheless, it is fair to suggest that available indicators of wealth and economic development, of regime type and quality can give us a rough picture of how states in reality fare with respect to sufficientarian international justice. All countries involved in investor-state arbitration lawsuits mentioned in the previous section are 'middle income' countries or above according to World Bank indicators. ${ }^{48}$ The poorer countries among them, Egypt and El-Salvador, are in the category of lower middle income countries. ${ }^{49}$ Some of the countries have relatively high levels of domestic inequality, ${ }^{50}$ and / or high levels of poverty. ${ }^{51}$ However, arguably with the exception of Egypt, means to alleviate poverty are present within all. Therefore, from the liberalstatist sufficiency perspective, there is no clear-cut case for international aid or a 'duty of assistance' in these cases. With the exception of Egypt, all countries mentioned are classified as democracies,, and have been in these categories for at least two decades. ${ }^{52}$ It is fair to suggest that, with the exception of Egypt with an authoritarian regime, countries do meet the liberal-statist threshold conditions of self-determination. Furthermore, liberal-statist theories do not require democracy as a necessary condition for recognizing a country as selfdetermining in the international context. ${ }^{53}$

47 On group agency and group freedom, see e.g., Christian List and Philip Pettit, Group Agency: The Possibility, Design and Status of Corporate Agents (Oxford, Oxford University Press, 2011); Carter (1999), Ch. 9; in the context of selfdetermination, see e.g., Anna Stilz, 'The Value of Self-Determination', in David Sobel, Peter Vallentyne and Steven Wall (eds.), Oxford Studies in Political Philosophy Volume 2 (Oxford: Oxford University Press, 2016), 98-127.

48 World Bank indicators of wealth and inequality by country are available at: <https://data.worldbank.org/country> (Accessed: 27 June 2017).

49 According to current World Bank data, Uruguay and the Czech Republic are high income countries, Ecuador and Argentina upper middle income countries, and El-Salvador and Egypt lower middle income countries <http://data. worldbank.org/country> (Accessed: 13 April 2017).

50 Argentina, Ecuador, Uruguay and El-Salvador with GINI coefficient above 40. <http://povertydata.worldbank.org/ poverty/home/> (Accessed: 13 April 2017).

51 Population living under national poverty line increased in Egypt between 2000 and 2010 from 16 to 25 or from 11 to 21 million people <http://povertydata.worldbank.org/poverty/country/EGY> In El Salvador between 2005-2015 around $35 \%$, decline in absolute poverty from 20 to $3 \%<\mathrm{http}$ //povertydata.worldbank.org/poverty/country/SLV> (Accessed: 13 April 2017).

52 Based on commonly used data for regime classification, e.g., POLITY IV data base, the Economist democracy index and Freedom House ranking.

53 John Rawls argues in favour of respect for decent societies, including decent hierarchical societies as equal parties to the law of peoples, Rawls (1999a), pp. 62-71. Critical discussion of this view, from a liberal internationalist and selfdetermination focused perspectives, see e.g., Michael Blake, Justice and Foreign Policy (Oxford: Oxford University Press, 2013) Ch. 3; Thomas Christiano, 'Self-Determination and the Human Right to Democracy, in Rowan Cruft et. al. (eds.) Philosophical Foundations of Human Rights (Oxford: Oxford University Press, 2015), 459-480. 
For some proponents of liberal internationalism this result is satisfactory and in line with their moral intuitions about fairness: self-determination, and the freedoms it consists in, means that some political communities would fare better than others; attempts to equalize outcomes would constitute unwarranted interference with these freedoms, rendering self-determination hollow. However, for others the intuition persists that the highly unequal distribution of benefits and burdens might have a detrimental knock-on effect on selfdetermination even when sufficiency is obtained. In the following section, I propose an alternative conception of the freedom that self-determination consists in, which indeed supports limit on relative international inequality as a requirement of international justice even from a statist perspective.

Objections to liberal-statist theories of international justice are many. The argument defended here is distinct in that it raises an internal objection. The objection is internal because it does not challenge two basic premises of the liberal-statist theories. First, self-determination is a core principle and value of international justice; second, the freedom constituted in self-determination is conceptualized as negative freedom. Before proceeding with the argument, let us address an objection from a liberal-statist perspective - the 'grounds of justice objection' - to the application egalitarian principles of socioeconomic justice in international contexts.

\section{The grounds of justice objection}

Egalitarian liberal-statist theories are committed to the view that egalitarian principles of socioeconomic distributive justice - e.g., the second principle of justice of Rawls's theory - which apply domestically, do not hold across borders. This is because the grounds of justice that give rise to egalitarian socioeconomic duties of distributive justice in the domestic context do not obtain internationally. Different liberal-statist arguments disagree on which specific feature of the domestic context gives rise to egalitarian duties of socioeconomic justice in a way that the international context does not - that is to say, they have different views about the ground of egalitarian justice. ${ }^{54}$ The value and principle of self-determination is one of the main arguments given in defence of the inapplicability of egalitarian duties of distributive justice internationally. The self-determination based argument is the following: it is argued meaningful exercise of self-determination is not compatible with global egalitarian justice among individuals. As Andrew Altman and Christopher Wellman argue, if states

54 Andrea Sangiovanni, 'Global Justice, Reciprocity and the State,' Philosophy and Public Affairs 35/1 (2007), 3-39; Michael Blake, 'Distributive Justice, State Coercion, and Autonomy,' Philosophy and Public Affairs 30/3 (2001) 25796; Rawls (1999a); David Miller (2007); David Miller, 'Against Global Egalitarianism,' in Gillian Brock (ed.), Current Debates in Global Justice (Springer, 2005), 55-70; Altman and Wellman (2009). 
were to discharge of egalitarian cosmopolitan duties of distributive justice 'it seems clear that the right of political self-determination would need to be highly qualified' and 'not much of significance would be left over.'55 Schemes of egalitarian socioeconomic distributive justice among individuals worldwide involve, also for disadvantaged, disrespect of their self-determination because they require standardization and uniformity that are likely to permit very little space for taking own collective decisions, at the domestic level. In terms of Rawls's theory of justice, the second principle of justice, which requires egalitarian socioeconomic justice, is grounded in the notion of society as a scheme of cooperation, whereby all participants are prima facie entitled equally to the fruits of this cooperation. Insofar as these forms of intensive cooperation are present within self-determining political units and not on a global scale, this ground of egalitarian justice does not obtain among individuals worldwide.

Due to value of self-determination, there appears to be no ground to claim equal shares across borders and no duty on the better-off to share their resources internationally according to egalitarian standards: the ground of justice that gives rise to egalitarian rights and duties domestically does not apply in this context. This view on the ground of justice, however, overlooks one possible scenario: that limits on international inequality might be demanded by selfdetermination itself. It is to this possible argument that I now turn.

\section{A liberal-egalitarian conception of negative freedom}

Liberal-statist theories of international justice conceptualize self-determination as a freedom, and specifically as negative freedom: the agent - the selfdetermining people or state - is free if they have the formal-legal permission to act, and meet the sufficiency threshold required for being functional. As we have seen above, in prominent liberal-statist theories of international justice the freedom of self-determining states or peoples consists in their formal international legal standing and permissions and absence of violent and coercive external interferences. Beyond the formal-legal permission to act and absence of direct, self-determining units are entitled, on this view, to reach a sufficiency threshold required for functionality. In analogy to individual freedom, the sufficiency threshold can be construed as conditions of the absence of physical disablement. Indeed, liberal-statist theories have been criticized for their endorsement of a narrow, negative conception of freedom that overlooks limitations and preventing condition that disable the exercise of self-determination and sovereignty, which positive and republican conceptions

55 Altman and Wellman (2009), pp. 123-4. 
of freedom take into account. ${ }^{56}$ While this critique is appealing, in particular for proponents of positive and republican freedom, it continues to be objected by liberals that, independently of global justice debates, negative freedom remains the most compelling conception of freedom. Therefore, I propose an internal critique of the negative conception of freedom in liberal-statist theories of selfdetermination and international justice, by drawing a distinction to another negative conception of freedom. Unlike positive conceptions of freedom, the liberal-egalitarian conception of negative freedom does not deem the absence of material means to be an un-freedom as such. Nevertheless, where agents do not possess a decent chance at exercising their freedom, the conditions of freedom are not met. Let us take a closer look at this point.

Freedom, according to MacCallum's classical definition, is a triadic relationship between an agent, a constraint, and an action:

' $\mathrm{x}$ is (is not) free from $\mathrm{y}$ to do (not do, become, not become) $\mathrm{z}$,' $\mathrm{x}$ ranges over agents, y ranges of such 'preventing conditions' as constraints, restrictions, interferences, and barriers, and z ranges over actions or conditions of character or circumstance. ${ }^{57}$

Conceptions of freedom diverge on what count as relevant preventing conditions - constraints, restrictions, interferences, and barriers. At the 'purely negative' end of the spectrum, only a physical barrier counts as a restriction of freedom. At the opposite end, informal cultural norms also constitute relevant restrictions on freedom. ${ }^{58}$ Additionally, theories of freedom can also be helpfully divided into 'exercise' and 'opportunity' conceptions. Exercise conceptions 'refer to the manner in which subjects act; saying that a person acts freely is to use an exercise concept.' Opportunity conceptions focus 'not on the way in which individuals use their opportunities, but on the availability of those opportunities themselves.'59 Self-determination is plausibly construed as an 'opportunity' freedom, insofar as the notion that a people should have the freedom to decide for itself. In other words, self-determination is primarily about the possibilities and opportunities open to peoples to form and shape their societies. The range of various positions on 'preventing conditions' leads to different opportunity conceptions of freedom: different understandings of what count as preventing

56 Miriam Ronzoni, 'Two Conceptions of State Sovereignty and their Implications for Global Institutional Design', Critical Review of International Social and Political Philosophy 15/5 (2012), 573-91. Cécile Laborde and Miriam Ronzoni, 'What is a Free State? Republican Internationalism and Globalisation,' Political Studies 64/2 (2016), 279-96.

57 Gerald MacCallum, 'Negative and Positive Freedom', The Philosophical Review 76/3 (1967), 312-34, p. 314.

58 Consider, for instance, how social norms are a barrier to freedom for feminists: Nancy Hirschman, 'Freedom, Recognition and Obligation: A Feminist Approach to Political Theory,' American Political Science Review 83/4 (1989), 1227-44; Nancy Fraser, Justice Interruptus: Critical Reflections on the 'Postsocialist' Condition (New York: Routldge, 1997).

59 Dowding and van Hees (2007), pp. 143-4. 
conditions entail different understandings of when an agent is opportunity free, namely when an opportunity is open to them. The longstanding, albeit contested, distinction between negative and positive freedom still helps map the array of views on when an agent is 'opportunity free.' The distinction itself between positive and negative conceptions can be drawn in different ways, but an important dimension of it is the weight given to the availability of material means. Under this understanding, an agent is negatively free to take the train to a seaside holidays if no law or another formal restriction prohibits her, no physical barrier blocks her and no serious threat to her life and limb deters her; she is, instead, positively free if she also has the means to purchase a ticket. In recent theorizing on freedom, issues of psychological constitution, as well cultural and social norms and capital are taken more often into account as potential barriers to opportunity freedom.

As we have noted, this is only one way of drawing the distinction between negative and positive freedom. What is more, there is a significant variation within each camp. In particular, negative freedom can be understood in two competing ways. 'Purely' negative conceptions recognize physical barriers alone as relevant restrictions on access. The 'Hobbesian' conception 'sees freedom simply as the absence of external physical or legal barriers.' 60 'Conventional' negative views, instead, also consider threats of sufficient magnitude to be constraints on freedom. ${ }^{61}$ The conventional negative view is most closely associated with classical liberalism. Nevertheless, in liberal-egalitarian theorizing a further negative conception of freedom is identifiable - one which takes into account the feasibility of accessing opportunities in view of potential material and social barriers.

Consider, for instance, Rawls's two principles of justice and how the theory's concern with socioeconomic and political equality also has implications for the interpretation of freedom itself. Rawls's famous first principle of social justice reads: 'Each person is to have an equal right to the most extensive scheme of equal basic liberties compatible with a similar scheme of liberties for others. ${ }^{26}$ Rawls explicitly seeks to 'bypass the dispute about the meaning of liberty,' namely 'the controversy between the proponents of negative and positive liberty as to how freedom should be defined', 63 noting that his 'remarks about the concept of liberty are unhappily abstract.' 64 Nonetheless, two pertinent points are made clear. First, endorsing MacCallum's general concept

60 Taylor (1979), p. 176.

61 Isaiah Berlin, 'Two Concepts of Liberty' in Four Essays on Liberty (Oxford: Oxford University Press, 1958), 118-72, pp. 122-31.

62 John Rawls, A Theory of Justice: Revised Edition (Cambridge: Harvard University Press, 1999b), p. 53

63 Ibid, p. 176.

64 Ibid, p. 179. 
of freedom (quoted above), Rawls specifies that 'constraints may range from duties and prohibitions defined by law to the coercive influences arising from public opinion and social pressure. ${ }^{65}$ Freedom, then, is not only the absence of formal constraints, but may also be restricted by informal yet powerful social norms and influences that prevent an agent from an action that they are formally permitted to perform. This specification is more extensive in its conception of pertinent constraints than conventional negative views usually are, in that it takes into account the powers of (at least some) informal social norms. At the same time, it is still a negative conception. Second, means to exercise freedom - material, cognitive or others - are not defined by Rawls as 'constraints definitive of liberty'66: the absence of material means, for instance, does not automatically constitute an unfreedom. Such means are not, however, entirely divorced from liberty, in that they are taken by Rawls to affect 'the value of liberty. ${ }^{97}$ The distinction between liberty and its value is drawn as follows: 'liberty is represented by the complete system of the liberties of equal citizenship, while the worth of liberty for persons and groups depends on upon their capacity to advance their ends within the framework the system defines. ${ }^{68}$ This capacity depends on means such as wealth and education and is not possessed by all to the same extent but; in the case of political liberties in particular, Rawls explicitly argues that citizens are not only entitled to those liberties, but also to their 'fair value.'

Crucially, the issue of the value of liberty is conceptually distinct, in Rawls's theory of justice, from equal access to social positions. The latter pertains directly to socioeconomic inequality - namely to the unequal advantages and burdens that are attached to different social positions. To remedy social inequality, 'fair equality of opportunity' is required: access to more advantageous positions must be genuinely open to all regardless of social background. Fair equality of opportunity and the fair value of liberty are two distinct components and ends of the theory. To sum up, we might say that Rawls's theory of justice as fairness, and arguably liberal egalitarianism more generally, is grounded on a negative conception of freedom, in that freedom is not fully identified with the means to exercise it. Freedom and the value of freedom are two conceptually distinct concepts. At the same time, the identification of the value of freedom as a problem in and of itself - distinct from distributive equality and equality of opportunity means that the concern of liberal egalitarianism with access to means is not exclusively a problem of social justice: it is an issue pertaining to

65 Ibid, p. 177.

66 Ibid, p. 179.

67 Ibid, p. 179.

68 Ibid, p. 179. 
freedom itself, in that the absence of means affects the quality and extent of liberties. This is a conception of negative freedom that takes into account the question of access to means to exercise freedom - the capacity to enjoy liberties and opportunities. A person that has the legal, formal, or moral freedom-rights, but no means to exercise them is not altogether unfree on this view, but the value of their liberty and its extent is a lesser one and faulty in comparison to those that have ample means to exercise their liberty. Other conceptions of negative freedom consider the problem of access to means an issue of social justice or not a matter of justice at all - in other words, as problem external to the freedom and its conception. Therefore, this liberal-egalitarian conception of negative freedom is distinct in a subtle but momentous way both from positive conceptions of liberty and other liberal and libertarian non-egalitarian conceptions thereof. ${ }^{69}$

\section{The quality and value of liberal-egalitarian negative liberty}

Let us now flesh out the notion of liberal-egalitarian negative freedom with an example. What does such a conception of freedom - which does not fully incorporate means of exercise into its definition of freedom, but nevertheless takes them into account-involve? Specifically, why does comparative inequality, beyond the threshold of sufficiency, matter from this perspective? Consider the following example. Andrea wishes to study medicine, and she meets the formal requirements for admission: there is no formal restriction on her admission and she has good enough grades to be admitted. However, places in medical school are scarce and Andrea is likely to need further preparation for the entry exam. Furthermore, to attend and complete medical school, substantive funds are needed for tuition and for subsistence during the long period of intensive studies and training. From a Rawlsian perspective on justice, Andrea's situation is raising a twofold concern from a normative perspective. Firstly, we are concerned by the benefits of the social position that are attach to the medical profession in Andrea's society, and want to make sure that everybody, including Andrea, has a fair chance to reach such a position. This is straightforwardly a matter of social justice governed by the principle of fair equality of opportunity. Secondly, Andrea's situation also raises concerns for the value of her liberty. If Andrea lacks the funds to purchase professional training for the entry exam

69 It is noteworthy that Ronald Dworkin's analysis of freedom, too, stipulates a strong commitment to equality. Dworkin famously argues that freedom itself ought to be interpreted in a way that renders it compatible with the principles of resources egalitarianism, defended in his theory of equality (Dworkin 1987). The compatibility of freedom and equality at the conceptual level, he argues, mitigates the need for tragic choices between equality and freedom and helps explain why resources egalitarianism is preferable to other conceptions of socioeconomic equality, which are not compatible with a plausible conception of freedom. See, Ronald Dworkin, 'What is Equality? Part 3: The Place of Liberty,' Iowa Law Review 73/1 (1987), 1-54. Ian Carter (1999) argues that this analysis of freedom is less attractive because it disregards the 'non-specific value of freedom.' It is not necessary to adopt Dworkin's solution to notice the relevance of the issue: liberal-egalitarian conceptions and theories of freedom take the value of equality into account. 
and to support herself during her studies, the value of her liberty to pursue a medical career is diminished.

Now, whereas the question of fair equality of opportunity to access social positions is connected to participation in the shared scheme of political cooperation, the value of liberty pertains to the very core of liberal autonomy and should, therefore, plausibly matter independently of one's participation in a scheme of cooperation from a liberal-egalitarian perspective ${ }^{70}$. Therefore, a liberal-egalitarian theory of international justice still ought to be committed to a conception of freedom that takes the value of liberty into account. It is not immediately clear which precise principle of justice is most appropriate in order to realize the value of liberty in the international context: The question deserves a careful consideration that lies beyond the scope of this article. My claim in the remainder of this article is, however, that even the most modest interpretation of the value of liberty at the international level would have farreaching consequences. Let us consider, for instance, a modest interpretation of 'the fair value' of a very important freedom at the international level, namely self-determination. An appropriate conception of the freedom that selfdetermination consists in, for a liberal-egalitarian statist theory of international justice, should indeed incorporate the value of liberty; the freedoms constituted in the principles of self-determination ought to have their fair value. ${ }^{71}$ This interpretation remains consistent with the statist premise that international justice is concerned, in the first instance, with interaction among selfdetermining peoples.

Let us recall Andrea and her chances of admission to, and completion of, medical school. Consider three scenarios. As in the case above, in all three scenarios Andrea has the formal liberty and natural talent to enter and complete medical school. The scenarios differ with respect to Andrea's means to exercise her liberty and her relative (dis)advantage. In the first scenario, (1) Andrea has no feasible access to the means to exercise her negative freedom to enter and complete medical school. Not only is her family unable to support her, they rely on her income for subsistence. Andrea's society has no schemes of social welfare nor grants or loans for students. Under these conditions, no matter how hard

70 This is not a complete argument for why liberal-egalitarian statist theory of international justice ought to safeguard fair value of liberty for all peoples. It suffices that the fair value of liberty does not fall within the domains of social justice, to which egalitarianism does not apply on the liberal statist view.

71 Another prima facie possible interpretation of the value of liberty in the context of international justice pertains to the claims that each individual qua individual worldwide has against domestic, international, and transnational institutions and practices. Insofar as transnational and international practices and institutions do not respect, enable or support fair value of liberty for all individuals, they perpetuate an injustice. This is interpretation is less likely compatible with the liberal-statist internationalist premise. Be that as it may, fair value of liberty for peoples in exercise of their freedoms constituted in self-determination is a matter of international justice, form a liberal-statist perspective, too, that deserve the theory's attention. 
Andrea might try and how well-suited her natural talents are, she has no feasible possibility to exercise her traditional negative freedom to enter medical school and complete her studies there. Her liberty is of little, if any, value. (2) Andrea is endowed with the same talents, formal qualifications and permissions as in the previous scenario and continues to lack financial support from her family. However, now her society sustains a system of social support that includes a safety net for students in need. The social support is modest. Still, it enables Andrea decent chances at admission to and completion of medical school. She is likely to need to put more effort to succeed, in comparison to candidates and fellow-students that possess more resources (material, cultural, or symbolic). Nevertheless, insofar as Andrea has decent chances to exercise the personal liberty of pursuing a career in the profession of her passion, her liberty has value.

To be sure, this value of liberty does not meet the requirements of domestic egalitarian justice - which (as noted above) demand fair equality of opportunity, as the appropriate standard for social justice and for fair value of liberty. Further, the notion of 'decent chances to exercise' freedom needs clarification and 'operationalization' - what indicates and counts as 'decent' in this context - a problem that lies beyond the scope of this article. Nonetheless, the comparison between the two scenarios illustrates and proposes a very modest conception of 'fair' value of liberty divorced from fair equality of opportunity and domestic equality. I do not suggest that a statist liberal-egalitarian theory of international should be satisfied with this modest conception; it may well be more ambitious. In the following section, however, I argue that even with a very modest conception of fair value of liberty, relative inequality - beyond the sufficiency threshold - matters for a liberal-statist theory of international justice.

\section{Self-determination and relative international inequality}

Let us briefly recapitulate this article's argument so far: self-determination is a central value and principle for liberal statist theories of international justice. Prominent liberal-statist theories conceive of self-determination as collective freedom of a people to self-government. They endorse implicitly a traditional negative, or Hobbesian, conception of negative freedom in their theorizing of self-determination, and subsequently defend a sufficiency threshold principle of international distributive justice. The practice of investor-state arbitration in private international law illustrates that liberal-statist theory of international justice has reasons to be concerned with relative distribution, beyond the sufficiency threshold, of benefits and burdens, in international contexts. An alternative, egalitarian, conception of negative freedom is then proposed that 
takes into account the value of liberty - the possibility and chances of agents to exercise their (negative) freedoms. It remains to be explained how the proposed liberal-egalitarian conception of negative freedom supports a principle of international distributive justice that takes relative inequality, beyond the threshold, into account, and to explore some preliminary implications for the practice of investor-state arbitration.

To this end, let us proceed to the third scenario regarding Andrea's chances in medical school. In this scenario Andrea has the same talents and formal qualifications as in the second, as well as access to the very same social safety net. What is different now, are the resources available to other candidates and applicants to medical studies. They are now far better-off then they were before: the support of their families expanded significantly the resources - material, cultural, and symbolic - available to them. Whereas in the second scenario it was assumed that the gap between Andrea and others is such that renders her chances to succeed decent, in the new scenario Andrea is disadvantaged in comparison to others to an extent that her chances to obtain a share of the scarce good - a place in medical school - are meagre. Her liberty is again devalued, akin to the first scenario. Comparative disadvantage affects the value of liberty and, therefore, it matters from a liberal-egalitarian conception of negative freedom. The point is not simply to have 'enough,' but to not have too much less than relevant others. ${ }^{72}$

The general analytical point here is not that we need to know how the betteroff fare, in order to determine what the appropriate sufficiency threshold is. ${ }^{73}$ The point is not (merely) to safeguard that all are above a designated threshold, but that all have decent chances to obtain the better-off position - a fair share of scarce goods, a fair share of the benefits. Self-determination conceptualized as freedom ought to have a fair value for the agents that exercise it. This article does not offer a considered view on what is 'fair' in this context. However, even under a very modest reading - indeed, one which may be too modest for a liberal-egalitarian position - comparative inequality must be taken into account. International investment law and the practice of foreign direct investment has enabled the creation of tremendous revenues and benefits, as well as weighty burdens. Where inequality among the parties that participate in the practice is dramatic and growing, the chances of the relatively worse-off to obtain a fair share of the overall benefits and avoid excessive burdens grow

72 The point is not limited to positional goods; access to non-positional scarce goods may well depend on how much others are capable of and willing to pay for them. Suppose that good-quality housing in a given town is scarce. The housing is of good quality not because some do not have it, but because the homes are specious, nicely designed and enjoy adequate municipal services. Assuming that the market determines the prices of houses in the town, the ability of each resident to access good-quality housing depends on how much other are ready and capable of paying.

73 This is an important and under-appreciated point in the debate about sufficiency principles of international distributive justice, but it does not genuinely challenge the sufficiency view. 
increasingly meagre. Subsequently, their self-determination is undermined in that the freedoms constituted in it lack their fair value.

In order to reach concrete action-guiding principles from the general conclusion that relative inequality beyond the threshold matters for selfdetermination, because peoples are owed a fair value of liberty in exercising their self-determination, much remains to be figured out still. Two preliminary suggestions, however, are in order. (1) The notion of fair value of liberty in the context of self-determination requires specifications for relative inequality between participant in specific transactions and interactions, and for conditions of background justice. Consider for example the case that opened this article - the Chevron / Ecuador lawsuits. The initial plaintiffs - the communities affected by the pollution in the Oriente region of Ecuador - are substantively worse-off in comparison to the corporation that they sued, in material and other resources. Thus, the specific interaction should be subject to principles of fair distribution of benefits and burdens that value of liberty of Ecuador's self-determination requires. However, looking at the effects of each and every interaction on overall distributions of benefits and burdens, and the associated chances of obtaining scarce resources, opens the door to numerous objections regarding complexity, uncertainty and unwarranted constraint on the freedom of participants to act. Applying the demands of fair value of liberty and associated distributions of benefits and burdens to principles of background justice is not readily liable to objections of this kind. ${ }^{74}$ Background justice in this context requires a general permanent limit on international inequality with regard those factors (to be specified) that pertain to the value of liberty in the exercise of self-determination, to safeguard decent chances for the relatively worse-off obtain fair benefits in their multiple interactions. ${ }^{75}$ (2) Selfdetermination is commonly seen as a right of peoples, exercised through state institutions, domestically and internationally. States, on this view, act in the international context on behalf of their peoples. Therefore, when examining the relationship between self-determination and international investment, specifically investor-state arbitration, the perspective of 'ordinary citizens' that collectively, as members of a people, hold the right to self-determination - ought to be considered. Theories of self-determination often look at the state and its peoples as unitary entity in the international context. However, a theory

74 On global justice as a case of background justice, see: Miriam Ronzoni, 'The Global Order: A Case of Background Injustice? A Practice-Dependent Account', Philosophy and Public Affairs 37/3 (2009), 229-56.

75 A third context of specification that merits attention beyond the scope of this article is the application of fair value of liberal, and associated distributions of benefits and burdens, to the practice of foreign direct investment. On practiceoriented methodology in theories of global justice, see e.g., Aaron James, 'Constructing Justice for Existing Practices: Rawls and the Status Quo,' Philosophy and Public Affairs 33/3 (2005), 281-316; Banai, Ronzoni and Schemmel (2013), pp. 50-60. 
of peoples' self-determination ought to pay attention to domestic inequality, and the way the international practice of direct investment and specifically investor-state arbitration affect these patterns of distribution of benefits and burdens within a single state. In other words, we need to take into account the burdens and barriers that members of the people face to exercising their commonly-held freedoms.

Before concluding, consider again the claim pertaining to minimum wages in Egypt, mentioned above. Proponents of investor-state arbitration argue that the corporation in this case does not in fact prevent the government from issuing the policy of raising minimum wages, nor does the claim for compensation threaten public policy autonomy. Rather, the argument goes, the arbitration claim seeks to safeguard that the government's contractual obligations to the corporation are kept, which possibly include a duty to pay compensation if operation costs for the corporation increase, as a result of government policy: 'the Egyptian government's ability to set its own minimum wage legislation has never been in question, and no ISDS award would be able to reverse the minimum wage hike, but only demand financial compensation for a specific contractual breach. ${ }^{76}$ From a liberal-statist perspective that endorses a sufficientarian conception of self-determination and international distributive justice, this argument is valid, if Egypt can be classified as being above the threshold. from the egalitarian liberal-statist perspective explored in this article provides, however, a very different answer. First, the notion that the claim to compensation generally does not affect the government's autonomy to set policies is only valid under a Hobbesian or conventional negative conception of freedom. However, for opportunity freedom to exist, burdens and obstacles to the exercise of formal liberties become relevant. The compensation claim thus affects government autonomy. It remains to be examined whether the obstacle is sizeable to the extent of rendering the agent opportunity unfree with respect to action. Second, the compensation claim affects the distribution of benefits and burdens associated with the interaction. Subsequently, it is pertinent to the problem of the value of liberty: where the distribution of burdens and benefits is highly unequal, the value of liberty of the worse-off party to the interaction is undermined. Thirdly, from the perspective of ordinary citizens and of the worse-off citizens that gain minimum wages or areotherwiseaffected by earning scalesconnected tominimum wages, the compensation claim is yet an additional obstacle to the difficulties they already face domestically in obtaining their fair share of socioeconomic goods and exercising self-determination. In other words, even if the country as a whole is above a sufficiency threshold or at a socioeconomic condition that

76 Patrick Carvalho, Investor-State Arbitration and the Rule of Law: Debunking the Myths - Research Report (The Center for Independent Studies, 2016) p. 21. 
enables opportunity freedom, it does not follow that the 'people' - understood as majority of citizens beyond powerful economic elites, have sufficient access to these benefits, so that the conditions of people's self-determination obtain. In sum, whereas from a Hobbesian conception of freedom, policy autonomy of a government is not affected by economic burdens and sanctions, from a liberalegalitarian conception of negative freedom socioeconomic conditions matter to the determination of whether self-determination has a fair value and whether peoples are opportunity free to exercise their self-determination.

\section{Conclusion}

Liberal-statist theories of international justice that value self-determination ought to take into account relative international inequality. The liberal-statist premise that principles of egalitarian social justice do not apply internationally does not support sufficiency as a standard of international distributive justice. From a liberal-egalitarian perspective, relative inequality matters for the fair value of self-determination. For self-determination to have a 'fair value' for the peoples that exercise it, relative international inequality ought to be limited. Specifications of this general requirement of limited inequality are left to be considered and figured out in future inquiry. Investor-state arbitration, within the practice of private international investment, enables us to identify this hitherto neglected aspect of the relationship between self-determination and international inequality beyond the sufficiency threshold. The liberty to enter international contracts and agreements is an established component of exercising self-determination, even when states take upon themselves, through the treaties and agreements that they enter, to limit their actions and policy choices in the future. At the same time, the highly unequal distribution of benefits and burdens related to this practice undermines self-determination's 'fair value of liberty' for the peoples that hold the right and exercise it. ${ }^{7}$

\section{Ayelet Banai \\ Lecturer in Politics \\ Department of Government and Political Theory \\ School of Political Sciences \\ The University of Haifa \\ email:abanai@poli.haifa.ac.il \\ the global justicenetwork}

77 For valuable and helpful comments on earlier versions of this article, I would like to thank: Suha Jubran-Ballan, Eszter Kollar, Miriam Ronzoni, the participants in the workshop Normative Reflections on the TTIP, June 2016 at the EUI, and to the editors and anonymous reviews of the Journal. Research for this article was supported by the Israel Science Foundation (grant no. 1127/16). 